\title{
Evaluation of Impacts from Radiological Air Emissions for the HALEU Environmental Assessment
}

\author{
A Jeffrey Sondrup
}

October 2018

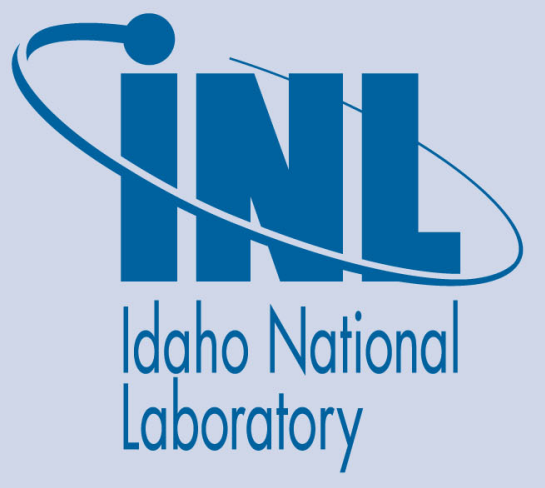

The INL is a U.S. Department of Energy National Laboratory operated by Battelle Energy Alliance 


\title{
Evaluation of Impacts from Radiological Air Emissions for the HALEU Environmental Assessment
}

\author{
A Jeffrey Sondrup
}

October 2018

Idaho National Laboratory Idaho Falls, Idaho 83415

http://www.inl.gov

Prepared for the

U.S. Department of Energy

Under DOE Idaho Operations Office

Contract DE-AC07-05ID14517 
TEM-10200-1

Rev. 08

Evaluation of Impacts from Radiological Air Emissions for the HALEU Environmental

Title: $\quad$ Assessment

$\begin{array}{lllll}\text { ECAR No.: } 4321 & \text { Rev. No.: } & 0 & \text { Project No.: N/A } & \text { Date: } 10 / 31 / 2018\end{array}$

\begin{tabular}{|c|c|c|}
\hline $\begin{array}{l}\text { Does this ECAR involve a } \\
\text { Safety SSC? }\end{array}$ & $\mathrm{N} / \mathrm{A}$ & \multirow{6}{*}{ PE Stamp Not Required per LWP-10010. } \\
\hline $\begin{array}{l}\text { Safety SSC } \\
\text { 2. Determination Document } \\
\text { ID }\end{array}$ & N/A & \\
\hline 3. Engineering Job (EJ) No. & $\mathrm{N} / \mathrm{A}$ & \\
\hline 4. SSC ID & $\mathrm{N} / \mathrm{A}$ & \\
\hline 5. Building & $\mathrm{N} / \mathrm{A}$ & \\
\hline 6. Site Area & MFC/INTEC & \\
\hline
\end{tabular}

7. Objective/Purpose:

This report contains an evaluation of radiological impacts to members of the public and collocated workers from potential air emissions resulting from production of high-assay low-enriched uranium (HALEU) fuel at Idaho National Laboratory (INL). This work considers impacts from presumed normal operations for the two alternatives outlined in Environmental Assessment for Use of DOEOwned HALEU Stored at INL (DOE-EA 2018).

8. If revision, please state the reason and list sections and/or pages being affected:

NA.

9. Conclusions/Recommendations

Conservative estimates of dose to workers and the public from atmospheric transport of potential radionuclide emissions are substantially less than applicable standards for both alternatives considered. Maximum estimated soil concentrations from the emissions were also determined to be less than conservative EPA risk-based screening levels. Because impacts are based on maximum, unabated/unmitigated potential emissions and other conservative or bounding assumptions, it is highly unlikely the alternatives evaluated in this ECAR will adversely impact human health. 
Rev. 08

Evaluation of Impacts from Radiological Air Emissions for the HALEU Environmental

Title: $\quad$ Assessment

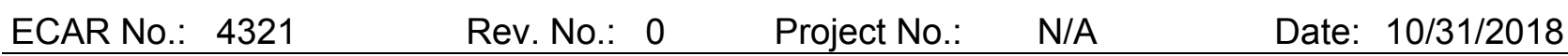

\section{CONTENTS}

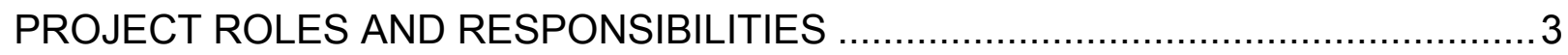

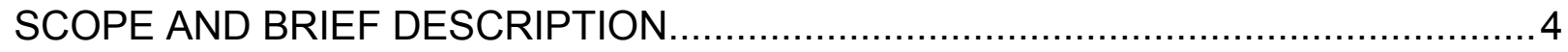

DESIGN OR TECHNICAL PARAMETER INPUT AND SOURCES …...................... 4

RESULTS OF LITERATURE SEARCHES AND OTHER BACKGROUND DATA .........5

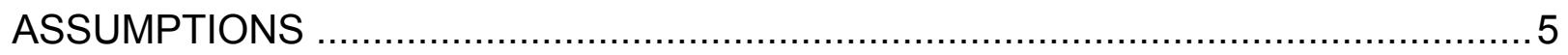

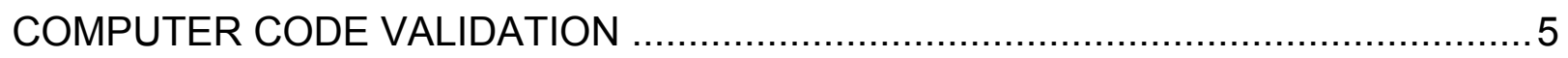

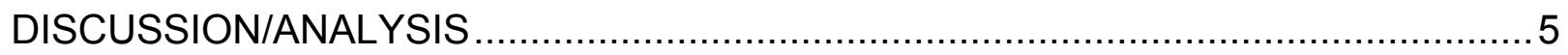

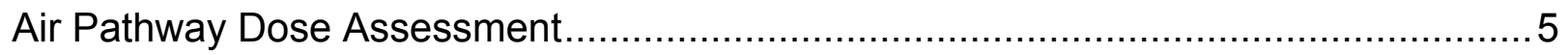

Source Term and Emissions Potential......................................................... 5

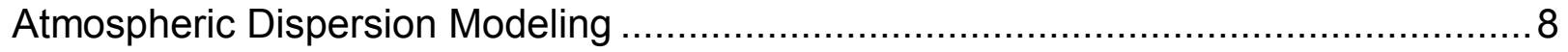

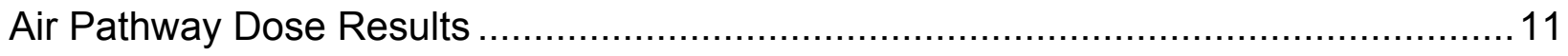

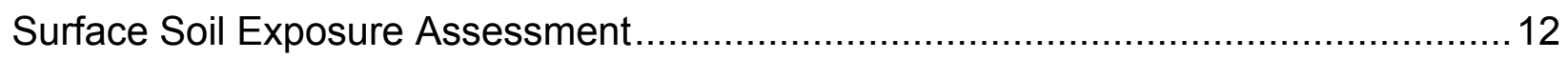

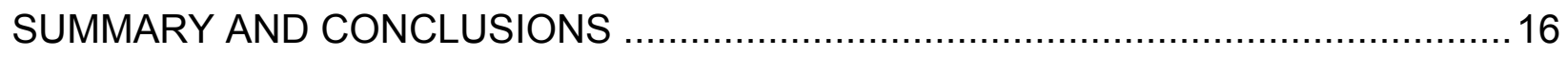

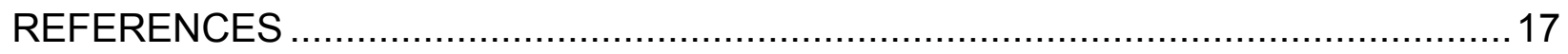

APPENDIXES

Appendix A, CAP88-PC Windfiles (EBRL6-15.WND, GRIL6-15.WND) 
Rev. 08

Evaluation of Impacts from Radiological Air Emissions for the HALEU Environmental

Title: $\quad$ Assessment

ECAR No.: 4321

Rev. No.: 0

Project No.:

N/A

Date: $10 / 31 / 2018$

PROJECT ROLES AND RESPONSIBILITIES

\begin{tabular}{|c|c|c|c|}
\hline Project Role & Name (Typed) & Organization & Pages covered (if applicable) \\
\hline Performer & A. Jeffrey Sondrup & B360 & eCR 663923 \\
\hline Checker $^{a}$ & Tim A. Solle & H510 & eCR 663923 \\
\hline Independent Reviewer ${ }^{b}$ & Mark A. Verdoorn & $\mathrm{H} 530$ & eCR 663923 \\
\hline CUI Reviewer ${ }^{c}$ & Ed Lee & M310 & STI INL/MIS-18-51849 \\
\hline Manager $^{d}$ & Brady J. Orchard & B360 & eCR 663923 \\
\hline Requestor ${ }^{\mathrm{e}}$ & John S. Irving & $\mathrm{J} 211$ & eCR 663923 \\
\hline Nuclear Safety ${ }^{\mathrm{e}}$ & $\mathrm{N} / \mathrm{A}$ & $\mathrm{N} / \mathrm{A}$ & \\
\hline Document Owner ${ }^{\mathrm{e}}$ & A. Jeffrey Sondrup & B360 & eCR 663923 \\
\hline
\end{tabular}
a. Confirmation of completeness, mathematical accuracy, and correctness of data and appropriateness of assumptions.
b. Concurrence of method or approach. See definition, LWP-10106.
c. Concurrence with the document's markings in accordance with LWP-11202.
d. Concurrence of procedure compliance. Concurrence with method/approach and conclusion.
e. Concurrence with the document's assumptions and input information. See definition of Acceptance, LWP-10200. 
TEM-10200-1

$12 / 19 / 17$

Rev. 08

Evaluation of Impacts from Radiological Air Emissions for the HALEU Environmental

Title: $\quad$ Assessment

$\begin{array}{lllll}\text { ECAR No.: } 4321 & \text { Rev. No.: } & 0 & \text { Project No.: } & \text { N/A }\end{array}$

\section{SCOPE AND BRIEF DESCRIPTION}

The U. S. Department of Energy (DOE) proposes to expand the fuel fabrication capability at Idaho National Laboratory (INL) to produce needed quantities of high-assay low-enriched uranium (HALEU) fuel from HALEU material (feedstock) stored at INL. The expansion of the fuel fabrication capability would include the purchase of new equipment and proposed use of existing facilities at INL's Materials Fuels Complex (MFC) and Idaho Nuclear Technology and Engineering Center (INTEC). This report contains an evaluation of radiological impacts to members of the public and collocated workers from potential air emissions resulting from HALEU fuel production at INL. This work considers impacts from presumed normal operations and supports the Environmental Assessment for Use of DOE-Owned HALEU Stored at Idaho National Laboratory (DOE-EA 2018).

The Environmental Assessment (EA) (DOE-EA 2018) proposes to process up to $5,000 \mathrm{~kg}$ of HALEU feedstock annually at INL. Alternative $1 \mathrm{a}$ of the EA proposes $2,500 \mathrm{~kg}$ be processed annually at each of two facilities at MFC, and Alternative $1 \mathrm{~b}$ proposes $2,500 \mathrm{~kg}$ be processed annually at an MFC facility and $2,500 \mathrm{~kg}$ processed annually at an INTEC facility.

Atmospheric dispersion and dose calculations for public and collocated worker receptors were performed in accordance with the requirements of Code of Federal Regulations (CFR), Title 40, "Protection of the Environment," Part 61, "National Emission Standards for Hazardous Air Pollutants (NESHAPs)," Subpart H, "National Emission Standards for Emissions of Radionuclides Other than Radon from Department of Energy Facilities" (40 CFR 61, Subpart H 2010). Emission potentials were calculated based on the methodology in 40 CFR 61, Appendix D and additional guidance/approval by EPA Region 10 (see letter from Donald Dossett [EPA Region 10] to Tim Safford [DOE-ID], Oct 19, 2017 [CCN 241475]) for solid materials that undergo heating. Estimates of total effective dose are based on low-level chronic exposure.

Additional impacts not considered by the CAP88-PC modeling-namely, incidental ingestion of contaminated soil and inhalation of fugitive dust (particulate matter)—were assessed by calculating conservative soil concentrations due to build-up of particulate deposition during operations, and comparing the concentrations to EPA preliminary remediation goals (PRGs). PRGs are risk-based screening levels that would not likely result in adverse health impacts under reasonable maximum exposure conditions for long-term/chronic exposures.

\section{DESIGN OR TECHNICAL PARAMETER INPUT AND SOURCES}

The following are sources for the primary data used in the assessment:

1. A representative radionuclide source term (radionuclide content of the HALEU feedstock material) was derived through a combination of measured values obtained by analysis and calculated values obtained by process modeling (see TEV-3537).

2. Melting points and boiling points of the radionuclides for determining emission potential were taken from the CRC Handbook of Chemistry and Physics http://hbcponline.com/faces/contents/InteractiveTable.xhtml?tableld=15.

3. Meteorological data from the MFC and GRID3 MESONET stations at INL were provided by the Idaho Falls National Ocean Atmospheric Administration (NOAA) Air Resources Laboratory. 
TEM-10200-1

$12 / 19 / 17$

Rev. 08

Evaluation of Impacts from Radiological Air Emissions for the HALEU Environmental

Title: $\quad$ Assessment

$\begin{array}{lllll}\text { ECAR No.: } 4321 & \text { Rev. No.: } & 0 & \text { Project No.: N/A } & \text { Date: } 10 / 31 / 2018\end{array}$

Other data sources and references are provided in the Discussion/Analysis section.

\section{RESULTS OF LITERATURE SEARCHES AND OTHER BACKGROUND DATA}

See Discussion/Analysis Section and References Section.

\section{ASSUMPTIONS}

See Discussion/Analysis Section.

\section{COMPUTER CODE VALIDATION}

All computer code modeling and calculations were performed on a Dell Optiplex 7020 computer (Intel Core i7-4790 CPU @ $3.60 \mathrm{GHz}$, property tag 604112) running Microsoft Windows 7 Enterprise, Service

Pack 1. Atmospheric transport modeling of radionuclide emissions was performed using the CAP88-PC Version 4 (EPA 2013a) computer model. CAP88-PC is a set of computer programs, databases, and associated utility programs for estimation of dose and risk from radionuclide emissions to the air. CAP88-PC is both a mature and the EPA-recommended model for demonstration of compliance with the applicable performance objective (40 CFR 61, Subpart $\mathrm{H}$ ). Testing and validation of CAP88-PC is performed by EPA and documented in EPA (2013b). Verification of proper installation and operation of CAP88-PC is performed annually at INL by simulating the example problem (Modtest) provided in the CAP88-PC download zip file. Additional information about CAP88-PC can be found at http://www.epa.gov/radiation/assessment/CAP88/aboutcap88.html.

Microsoft Excel 2013 (15.0.5041.1000) MSO (15.0.5031.1000) 32 bit, part of Microsoft Office Professional Plus 2013, was used for supporting calculations and creating graphs of results. Cell formulas were checked for accuracy, and a sample of the calculations were checked by hand. All formula cells have been locked for editing and password protected.

All electronic files, including computer input, output, and spreadsheet files are contained in a zip file that can be accessed by selecting "Additional Information" (select Native File) in the INL Electronic Document Management System.

\section{DISCUSSION/ANALYSIS}

\section{Air Pathway Dose Assessment}

\section{Source Term and Emissions Potential}

This evaluation assumes a maximum annual production rate of 2,500 $\mathrm{kg}$ per facility which equates to 50 batches of $50 \mathrm{~kg}$ each HALEU feedstock material. Table 1 contains the radionuclide activity in 2,500 $\mathrm{kg}$ of HALEU feedstock material. This was determined using the radionuclide composition in HALEU feedstock material from TEV-3537 (column 2), to determine the mass in 2,500 kg of HALEU material (column 3), that was converted to activity (column 5) using radionuclide specific-activity values (column 4). The inventory in Table 1 includes all major nuclides whose concentrations were measured by analysis or determined by modeling; other nuclides, including radioactive decay products, may be present at very low concentrations but it is highly unlikely they would contribute to the estimated dose. 
TEM-10200-1

$12 / 19 / 17$

Rev. 08

Evaluation of Impacts from Radiological Air Emissions for the HALEU Environmental

Title: $\quad$ Assessment

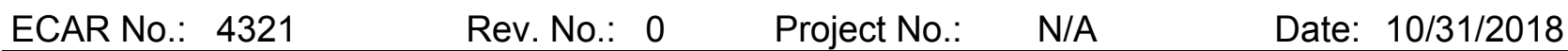

Table 1. Composition of HALEU feedstock material.

\begin{tabular}{|c|c|c|c|c|}
\hline Radionuclide & Composition & $\begin{array}{c}\text { Mass in } \\
2,500 \mathrm{~kg} \text { Feedstock } \\
(\mathrm{g})\end{array}$ & $\begin{array}{l}\text { Radionuclide } \\
\text { Specific } \\
\text { Activity (Ci/g) } \\
\end{array}$ & $\begin{array}{c}\text { Activity in } \\
2,500 \text { kg Feedstock } \\
\text { (Ci) }\end{array}$ \\
\hline Mn-54 & 3.04E-06 ppm ${ }^{a}$ & 7.60E-06 & $7.75 \mathrm{E}+03$ & $5.89 \mathrm{E}-02$ \\
\hline Co-60 & $2.78 \mathrm{E}-05 \mathrm{ppm}^{\mathrm{a}}$ & 6.95E-05 & $1.13 E+03$ & 7.86E-02 \\
\hline Sr-90 & $1.58 \mathrm{E}-02 \mathrm{ppm}^{\mathrm{a}}$ & 3.94E-02 & $1.37 E+02$ & $5.40 \mathrm{E}+00$ \\
\hline Tc-99 & $1.50 \mathrm{E}-01 \mathrm{ppm}^{\mathrm{a}}$ & 3.75E-01 & $1.71 \mathrm{E}-02$ & $6.41 \mathrm{E}-03$ \\
\hline Sb-125 & 1.03E-04 ppm ${ }^{a}$ & $2.56 \mathrm{E}-04$ & $1.04 \mathrm{E}+03$ & 2.67E-01 \\
\hline Cs-134 & $2.50 \mathrm{E}-05 \mathrm{ppm}^{\mathrm{a}}$ & $6.25 \mathrm{E}-05$ & $1.29 E+03$ & 8.06E-02 \\
\hline Cs-135 & $2.67 \mathrm{E}+00 \mathrm{ppm}^{\mathrm{a}}$ & $6.68 E+00$ & 1.15E-03 & 7.68E-03 \\
\hline Cs-137 & $8.00 \mathrm{E}-03 \mathrm{ppm}^{\mathrm{a}}$ & $2.00 \mathrm{E}-02$ & $8.68 \mathrm{E}+01$ & $1.74 \mathrm{E}+00$ \\
\hline Ce-144 & $6.71 \mathrm{E}-05 \mathrm{ppm}^{\mathrm{a}}$ & $1.68 \mathrm{E}-04$ & $3.18 E+03$ & 5.34E-01 \\
\hline Eu-154 & $2.20 \mathrm{E}-04 \mathrm{ppm}^{\mathrm{a}}$ & 5.50E-04 & $2.70 E+02$ & $1.49 \mathrm{E}-01$ \\
\hline Eu-155 & $2.20 \mathrm{E}-04 \mathrm{ppm}^{\mathrm{a}}$ & 5.50E-04 & $4.85 E+02$ & 2.67E-01 \\
\hline $\mathrm{Np}-237$ & $1.71 \mathrm{E}+01 \mathrm{ppm}^{\mathrm{a}}$ & $4.28 E+01$ & 7.05E-04 & 3.02E-02 \\
\hline Pu-239 & $8.36 \mathrm{E}+01 \mathrm{ppm}^{\mathrm{a}}$ & $2.09 E+02$ & 6.21E-02 & $1.30 \mathrm{E}+01$ \\
\hline Pu-240 & $2.24 \mathrm{E}+00 \mathrm{ppm}^{\mathrm{a}}$ & $5.60 E+00$ & $2.27 \mathrm{E}-01$ & $1.27 E+00$ \\
\hline Am-241 & 6.12E-02 ppm ${ }^{\mathrm{a}}$ & $1.53 \mathrm{E}-01$ & $3.43 E+00$ & $5.25 \mathrm{E}-01$ \\
\hline U-234 & $1.60 \mathrm{E}-03 w t \% \mathrm{U}^{\mathrm{a}, \mathrm{b}}$ & $3.99 \mathrm{E}+03$ & $6.21 \mathrm{E}-03$ & $2.48 E+01$ \\
\hline U-235 & $1.93 E-01 w t \% U^{a, b}$ & $4.80 E+05$ & $2.16 \mathrm{E}-06$ & $1.04 \mathrm{E}+00$ \\
\hline U-236 & $5.20 \mathrm{E}-03 \mathrm{wt} \% \mathrm{U}^{\mathrm{a}, \mathrm{b}}$ & $1.30 E+04$ & 6.47E-05 & 8.38E-01 \\
\hline U-238 & 7.98E-01 wt\% $\% \mathrm{U}^{\mathrm{a}, \mathrm{b}}$ & $1.99 E+06$ & 3.36E-07 & 6.68E-01 \\
\hline U-232 & 5.04E-03 ppmU $\mathrm{U}^{\mathrm{C}}$ & $1.26 \mathrm{E}-02^{\mathrm{d}}$ & $2.20 \mathrm{E}+01$ & 2.77E-01 \\
\hline U-233 & 3.18E-01 ppmU ${ }^{\mathrm{c}}$ & $7.96 \mathrm{E}-01^{\mathrm{d}}$ & $9.64 \mathrm{E}-03$ & 7.67E-03 \\
\hline U-237 & 2.20E-07 ppmU ${ }^{\mathrm{c}}$ & $5.50 \mathrm{E}-07^{d}$ & $8.16 \mathrm{E}+04$ & 4.49E-02 \\
\hline
\end{tabular}

\footnotetext{
a. Average composition determined from elemental analysis of HALEU feedstock material (TEV-3537, Appendix C).

b. $\quad$ Based on average total weight percent uranium of $99.67 \%$ (TEV-3537, Appendix C).

c. Maximum value determined from process modeling (TEV-3537, Appendix B). Maximum values were used to account for uncertainty in the modeling.

d. Based on maximum total weight percent uranium of $99.97 \%$ (TEV-3537, Appendix B).

e. $\quad$ Specific activity for pure radionuclide calculated as $\lambda \times N_{A} /$ (Isotopic Weight $\times 3.7 \mathrm{E}+10$ ) where $\lambda=\ln (2) /$ half-life (sec), and $\mathrm{N}_{\mathrm{A}}$ is Avogadro's constant 6.02214E+23 atoms/mole. Half-lives taken from NNDC (2018).
}

To determine the emission potential from each facility, radionuclide activities in Table 1 were multiplied by appropriate emission factors based on the physical state of the HALEU feedstock material during processing. Because the material could undergo heating, an alternative to the method in 40 CFR 61 Appendix D, approved for use at INL by EPA Region 10 (see letter from Donald Dossett [EPA Region 10] to Tim Safford [DOE-ID] Oct 19, 2017 [CCN 241475]) was used to determine the emission factors for radioactive solid materials with high melting and boiling points. These emission factors are:

- 1 for radioactive solid materials heated to temperatures greater than or equal to $90 \%$ of the boiling or subliming point.

- $10^{-3}$ for radioactive solid materials heated to temperatures greater than or equal to their melting point but less than $90 \%$ of their boiling or subliming point. 
TEM-10200-1

$12 / 19 / 17$

Rev. 08

Evaluation of Impacts from Radiological Air Emissions for the HALEU Environmental

Title: $\quad$ Assessment

$\begin{array}{lllll}\text { ECAR No.: } 4321 & \text { Rev. No.: } & 0 & \text { Project No.: N/A } & \text { Date: } 10 / 31 / 2018\end{array}$

- $10^{-6}$ for radioactive solid materials heated to temperatures above ambient temperature but less than their melting point.

During processing, the HALEU feedstock material will be heated to an approximate maximum temperature of $1500^{\circ} \mathrm{C}$ (sintering) or $2000^{\circ} \mathrm{C}$ (arc melting) depending on the process selected. For this analysis, the higher maximum temperature was used to determine the emission factor for each radionuclide. Table 2 presents the melting point and $90 \%$ of boiling point for each radionuclide, the emission factor, and the annual emission potential. The emission potential is the product of the activity inventory and the emission factor and represents the amount that could potentially be released from the facility annually.

Table 2. Unabated annual radionuclide potential to emit for 2,500 kg HALEU feedstock material.

\begin{tabular}{|c|c|c|c|c|c|}
\hline Radionuclide & $\begin{array}{c}\text { Activity in } \\
2,500 \mathrm{~kg}(\mathrm{Ci})^{\mathrm{a}}\end{array}$ & $\begin{array}{c}\text { Melting } \\
\text { Point }(\mathrm{C})^{\mathrm{b}}\end{array}$ & $\begin{array}{l}90 \% \text { Boiling } \\
\text { Point }(C)^{b}\end{array}$ & $\begin{array}{l}\text { Emission } \\
\text { Factor }^{c}\end{array}$ & $\begin{array}{c}\text { Emission } \\
\text { Potential } \\
\text { (Ci/yr) }\end{array}$ \\
\hline $\mathrm{Mn}-54$ & 5.89E-02 & $1.25 \mathrm{E}+03$ & $1.85 \mathrm{E}+03$ & 1 & $5.89 \mathrm{E}-02$ \\
\hline Co-60 & 7.86E-02 & $1.50 \mathrm{E}+03$ & $2.63 E+03$ & 0.001 & $7.86 \mathrm{E}-05$ \\
\hline Sr-90 & $5.40 \mathrm{E}+00$ & $7.77 \mathrm{E}+02$ & $1.24 \mathrm{E}+03$ & 1 & $5.40 E+00$ \\
\hline Tc-99 & 6.41E-03 & $2.16 \mathrm{E}+03$ & $3.84 \mathrm{E}+03$ & 0.000001 & 6.41E-09 \\
\hline Sb-125 & 2.67E-01 & $6.31 \mathrm{E}+02$ & $1.43 E+03$ & 1 & 2.67E-01 \\
\hline Cs-134 & 8.06E-02 & $2.85 \mathrm{E}+01$ & $6.04 \mathrm{E}+02$ & 1 & 8.06E-02 \\
\hline Cs-135 & $7.68 \mathrm{E}-03$ & $2.85 E+01$ & $6.04 \mathrm{E}+02$ & 1 & $7.68 \mathrm{E}-03$ \\
\hline Cs-137 & $1.74 \mathrm{E}+00$ & $2.85 E+01$ & $6.04 E+02$ & 1 & $1.74 \mathrm{E}+00$ \\
\hline Ce-144 & 5.34E-01 & $7.99 E+02$ & $3.10 \mathrm{E}+03$ & 0.001 & 5.34E-04 \\
\hline Eu-154 & 1.49E-01 & $8.22 E+02$ & $1.38 E+03$ & 1 & 1.49E-01 \\
\hline Eu-155 & 2.67E-01 & $8.22 E+02$ & $1.38 \mathrm{E}+03$ & 1 & 2.67E-01 \\
\hline $\mathrm{Np}-237$ & 3.02E-02 & $6.44 \mathrm{E}+02$ & $3.51 \mathrm{E}+03$ & 0.001 & $3.02 E-05$ \\
\hline Pu-239 & $1.30 \mathrm{E}+01$ & $6.40 \mathrm{E}+02$ & $2.91 \mathrm{E}+03$ & 0.001 & 1.30E-02 \\
\hline Pu-240 & $1.27 E+00$ & $6.40 \mathrm{E}+02$ & $2.91 E+03$ & 0.001 & 1.27E-03 \\
\hline Am-241 & $5.25 E-01$ & $1.18 \mathrm{E}+03$ & $1.81 \mathrm{E}+03$ & 1 & $5.25 E-01$ \\
\hline U-234 & $2.48 \mathrm{E}+01$ & 1.14E+03 & $3.72 E+03$ & 0.001 & 2.48E-02 \\
\hline U-235 & $1.04 \mathrm{E}+00$ & $1.14 \mathrm{E}+03$ & $3.72 E+03$ & 0.001 & 1.04E-03 \\
\hline U-236 & 8.38E-01 & $1.14 \mathrm{E}+03$ & $3.72 E+03$ & 0.001 & 8.38E-04 \\
\hline U-238 & $6.68 \mathrm{E}-01$ & $1.14 \mathrm{E}+03$ & $3.72 \mathrm{E}+03$ & 0.001 & 6.68E-04 \\
\hline U-232 & 2.77E-01 & $1.14 \mathrm{E}+03$ & $3.72 E+03$ & 0.001 & 2.77E-04 \\
\hline U-233 & 7.67E-03 & $1.14 \mathrm{E}+03$ & $3.72 E+03$ & 0.001 & 7.67E-06 \\
\hline U-237 & 4.49E-02 & $1.14 \mathrm{E}+03$ & $3.72 \mathrm{E}+03$ & 0.001 & 4.49E-05 \\
\hline
\end{tabular}

For this analysis, doses were calculated for unmitigated emissions. No credit was taken for filtration even though processing will likely take place in a double high-efficiency particulate air (HEPA) filtered facility. Each stage of HEPA filtration removes $99.97 \%$ of airborne particulate material. It is likely that much of the radionuclide inventory that could become gaseous during processing would cool, solidify and be captured by the HEPA filters before emission. Nevertheless, the analysis does not credit the HEPA filtration. 
TEM-10200-1

Rev. 08

Evaluation of Impacts from Radiological Air Emissions for the HALEU Environmental

Title: $\quad$ Assessment

$\begin{array}{lllll}\text { ECAR No.: } 4321 & \text { Rev. No.: } & 0 & \text { Project No.: N/A } & \text { Date: } 10 / 31 / 2018\end{array}$

\section{Atmospheric Dispersion Modeling}

Atmospheric-dispersion modeling of radionuclide emissions was conducted according to guidance for performing environmental compliance-driven air modeling of emissions from INL facilities (Staley et al. 2004). Emissions were modeled from a stack similar to the Irradiated Materials Characterization Laboratory (IMCL) stack at MFC. This stack is approximately $15 \mathrm{~m}$ tall, with an exit diameter of $0.6 \mathrm{~m}$ and an exit velocity of $13 \mathrm{~m} / \mathrm{s}$. Each facility is likely to have a stack similar to this.

Doses were calculated at the following locations for each alternative:

- INL Site boundary nearest MFC: Located $400 \mathrm{~m}$ north of INL East entrance on Highway 20. This location is accessible to the public, but there are no permanent residents or public receptors. Regulatory dose limits do not apply at this location. Doses are presented only for reference.

- INL Site boundary nearest INTEC: Located approximately $14 \mathrm{~km}$ directly south of the INTEC entrance and $10 \mathrm{~km}$ east of Atomic City. The distance to INL's Site boundary northwest of INTEC is approximately the same distance, but the dose at the south receptor is higher. This location is accessible to the public, but there are no permanent residents or public receptors. Regulatory dose limits do not apply at this location. Doses are presented only for reference.

- Residence nearest MFC: This is a farmhouse located $3.1 \mathrm{~km}$ south of Highway 20, $3 \mathrm{~km}$ from INL's East entrance. Regulatory dose limits apply at this location.

- Atomic City: This town of population 29 (2010 census) is located approximately $2 \mathrm{~km}$ east of INL's South entrance on Highway 26. The residence nearest INTEC is located in Atomic City. Atomic City is approximately $21 \mathrm{~km} \mathrm{SW}$ of MFC and $17 \mathrm{~km} \mathrm{SE}$ of INTEC. Regulatory dose limits apply at this location.

- Frenchman's Cabin: This location is approximately $2 \mathrm{~km}$ south of the southern INL Site boundary near Big Southern Butte. This location is used to show INL Site compliance with 40 CFR 61, Subpart H - National Emissions Standards for Hazardous Air Pollutants (NESHAPs) Other Than Radon From Department of Energy Facilities, and is the location of the INL Site maximally exposed individual (MEI). The site may be inhabited during portions of the year, but there are no permanent residents. Regulatory dose limits do apply to this location because of the potential for occupation during a portion of the year.

The above locations are shown in Figure 1 along with the distance from the sources rounded to the nearest $\mathrm{km}$. 
TEM-10200-1

$12 / 19 / 17$

Rev. 08

Title: $\quad$ Evaluation of

$\begin{array}{lllll}\text { ECAR No.: } 4321 \quad \text { Rev. No.: } 0 & \text { Project No.: N/A } \quad \text { Date: } 10 / 31 / 2018\end{array}$

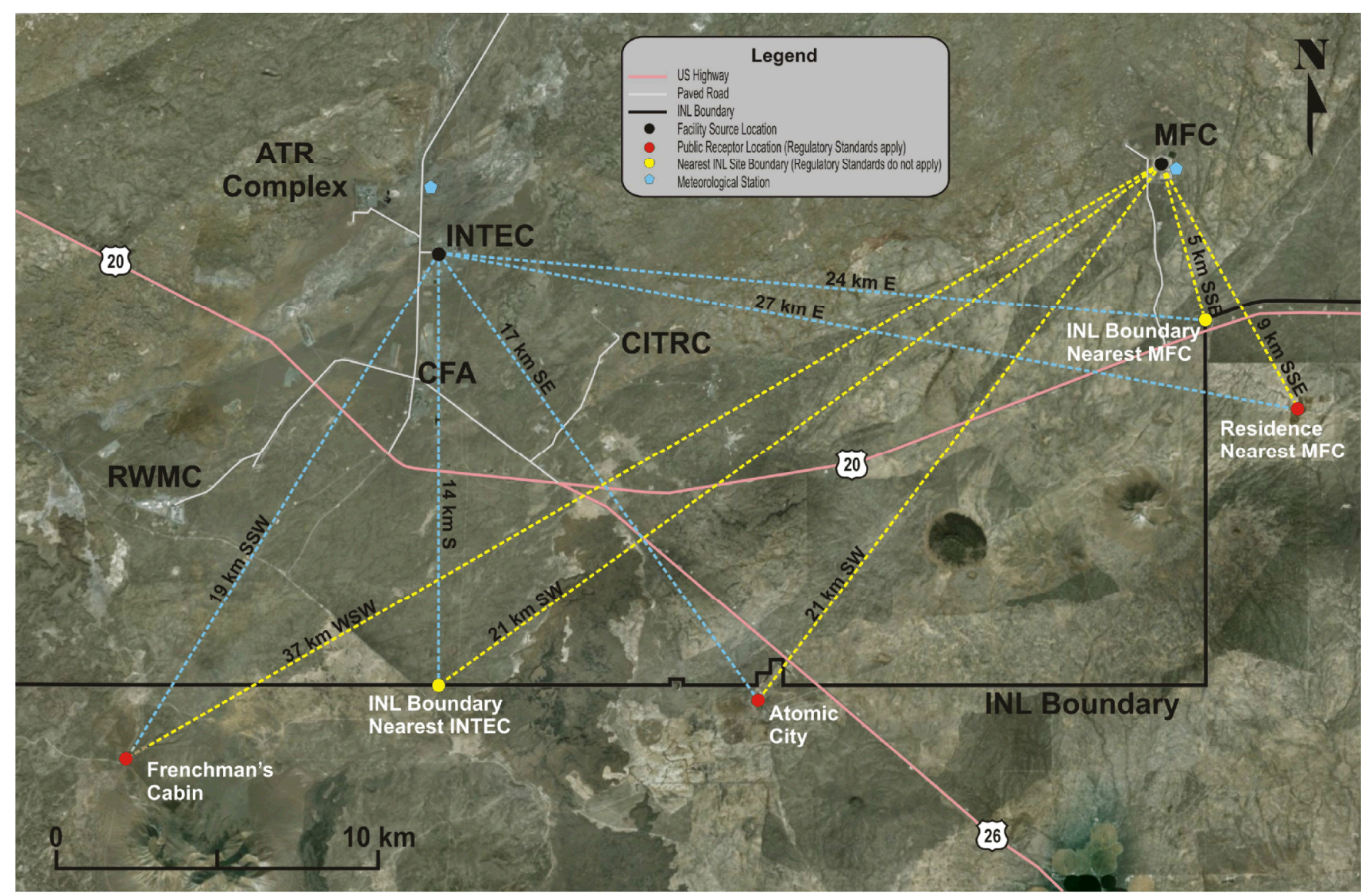

Figure 1. Public receptor locations for the air pathway analysis showing distance and direction from MFC and INTEC. Regulatory dose limits do not apply at the nearest boundary locations.

Collocated worker doses were calculated at $100 \mathrm{~m}$ from each source in the direction of maximum dose. For Alternative 1a, the public doses and worker doses were calculated assuming the two facilities at MFC are collocated. This is done by doubling the dose from processing 2,500 kg HALEU feedstock material. This is appropriate for the public dose since the nearest receptors are several km away and any difference in the locations is likely to be small compared to the distance to the receptor. It is conservative and bounding for the collocated worker with respect to where the facilities will be located.

Both public and worker doses were calculated using adult dose coefficients. Public receptor doses were calculated using the "local" food-production option in CAP88-PC to simulate a subsistence-farming scenario where all food products are grown at the receptor location. The CAP88-PC Version 4.0 default parameters for this exposure scenario are shown in Table 3. The collocated worker doses were calculated using the "imported" food-production option. In this case, there is no ingestion dose because the worker does not consume contaminated food products from the receptor location or assessment area. The inhalation, air-immersion and direct-ground-radiation doses for workers output from CAP88PC were scaled to account for reduced time onsite. The scale factor is $0.228=2000$ (annual work hours onsite) $\div 8766$ (hours in 1 year). 
Rev. 08

\section{Evaluation of Impacts from Radiological Air Emissions for the HALEU Environmental}

Title: $\quad$ Assessment

$\begin{array}{lllll}\text { ECAR No.: } 4321 \quad \text { Rev. No.: } & 0 & \text { Project No.: } & \text { N/A } & \text { Date: } 10 / 31 / 2018\end{array}$

Table 3. CAP88-PC Version 4.0 radionuclide-independent parameters for the public receptor scenario.

\begin{tabular}{|c|c|c|}
\hline Parameter Description & Value & Units \\
\hline Inhalation rate & $5.263 \mathrm{E}+03$ & $\mathrm{~m}^{3} /$ year \\
\hline Effective surface density of soil, dry weight (assumes $15 \mathrm{~cm}$ plow depth) & 215 & $\mathrm{~kg} / \mathrm{m}^{2}$ \\
\hline Build-up time for radionuclides in soil & $100^{\mathrm{a}}$ & year \\
\hline Build-up time radionuclides deposited on ground/water & $3.65 \mathrm{E}+04$ & day \\
\hline Delay time, ingestion of pasture grass by animals & 0 & $\mathrm{hr}$ \\
\hline Delay time, ingestion of stored feed by animals & 2160 & $\mathrm{hr}$ \\
\hline Delay time, ingestion of leafy vegetables by man & 336 & $\mathrm{hr}$ \\
\hline Delay time, ingestion of produce by man & 336 & $\mathrm{hr}$ \\
\hline Delay time, transport time from animal feed-milk-man & 2 & day \\
\hline Delay time, time from animal slaughter to consumption & 20 & day \\
\hline Removal rate constant for physical loss by weathering & 2.90E-03 & $1 / \mathrm{hr}$ \\
\hline Crop exposure duration, pasture grass & 720 & $\mathrm{hr}$ \\
\hline Crop exposure duration, crops or leafy vegetables & 1440 & $\mathrm{hr}$ \\
\hline Agricultural productivity, grass-cow-milk-man pathway & 0.28 & $\mathrm{~kg} / \mathrm{m}^{2}$ \\
\hline Agricultural productivity, produce/leafy vegetables for human consumption & 0.716 & $\mathrm{~kg} / \mathrm{m}^{2}$ \\
\hline Fallout interception fraction, vegetables & 0.2 & --- \\
\hline Fallout interception fraction, pasture & 0.57 & --- \\
\hline Fraction of year animals graze on pasture & 0.4 & --- \\
\hline Fraction of daily feed that is pasture grass (when animal on pasture) & 0.43 & --- \\
\hline Animal consumption rate of contaminated feed/forage (dry weight) & 15.6 & kg/day \\
\hline Milk production of cow & 11 & L/day \\
\hline Muscle mass of animal at slaughter & 200 & $\mathrm{~kg}$ \\
\hline Fraction of animal herd slaughtered per day & 3.81E-03 & -- \\
\hline Fraction of radioactivity retained after washing (leafy veg \& produce) & 0.5 & --- \\
\hline Fraction of produce ingested grown in garden of interest & 1 & --- \\
\hline Fraction of leafy vegetables ingested grown in garden of interest & 1 & --- \\
\hline Human produce ingestion rate & 76.2 & $\mathrm{~kg} /$ year \\
\hline Human milk ingestion rate & 53 & L/year \\
\hline Human meat ingestion rate & 84 & $\mathrm{~kg} / \mathrm{year}$ \\
\hline Human leafy vegetable ingestion rate & 7.79 & $\mathrm{~kg} /$ year \\
\hline Fraction of time spent swimming & 0 & --- \\
\hline Depth of water for dilution for water immersion doses & 1 & $\mathrm{~cm}$ \\
\hline Fraction vegetables home produced & $1^{\mathrm{b}}$ & --- \\
\hline Fraction milk home produced & $1^{\mathrm{b}}$ & --- \\
\hline Fraction meat home produced & $1^{\mathrm{b}}$ & --- \\
\hline Fraction vegetables from assessment area & $0^{\mathrm{b}}$ & --- \\
\hline Fraction meat from assessment area & $0^{\mathrm{b}}$ & --- \\
\hline Fraction meat from assessment area & $0^{\mathrm{b}}$ & --- \\
\hline Minimum ingestion fractions from outside area, vegetables & 0 & -- \\
\hline Minimum ingestion fractions from outside area, meat & 0 & --- \\
\hline Minimum ingestion fractions from outside area, milk & 0 & --- \\
\hline Default beef cattle density & $7.19 \mathrm{E}-02^{\mathrm{C}}$ & \#/ha \\
\hline Milk cattle density & $8.56 \mathrm{E}-03^{\mathrm{C}}$ & \#/ha \\
\hline Land fraction cultivated for vegetables & $7.15 \mathrm{E}-02^{\mathrm{C}}$ & -- \\
\hline $\begin{array}{l}\text { a. 100-year buildup time is required for NESHAP compliance demonstration. The b } \\
\text { isotopes accumulate in the soil based upon continuous deposition, decay, and } \\
\text { end of the buildup period is the one used as input to the dose and risk calculatio } \\
\text { this assessment because the facility is expected to operate only a few years. }\end{array}$ & $\begin{array}{l}\text { the length of } \\
\text { isotopic profile } \\
\text { conservative as }\end{array}$ & $\begin{array}{l}\text { that } \\
\text { e soil at the } \\
\text { iption for }\end{array}$ \\
\hline $\begin{array}{l}\text { b. Value for a local food-source option. Options are urban, rural, local, regional, or i } \\
\text { are grown at the receptor location (i.e., home produced). }\end{array}$ & cal assumes al & products \\
\hline c. Values specific to the State of Idaho. & & \\
\hline
\end{tabular}


TEM-10200-1

$12 / 19 / 17$

ENGINEERING CALCULATIONS AND ANALYSIS

Page 11 of 18

Rev. 08

Evaluation of Impacts from Radiological Air Emissions for the HALEU Environmental

Title: $\quad$ Assessment

$\begin{array}{lllll}\text { ECAR No.: } 4321 & \text { Rev. No.: } & 0 & \text { Project No.: N/A } & \text { Date: } 10 / 31 / 2018\end{array}$

\section{Meteorological Data}

Meteorological data files were provided by the Idaho Falls Office of the National Oceanic and Atmospheric Administration (NOAA). Meteorological monitoring stations are located near each of the major INL facilities. Data from the MFC station located immediately east of MFC was used for MFC simulations, and data from the GRID3 station located $1.5 \mathrm{~km}$ north of INTEC was used for INTEC simulations (see Figure 1). Data from the lower measurement height $(10 \mathrm{~m})$ of each station was used. Stability array ( ${ }^{*}$.str) files provided by NOAA were converted to wind $\left({ }^{*}\right.$.wnd) files using the computer program WINDGET and read directly by CAP88-PC. The wind files are presented in Appendix A. Other meteorological data used in the modeling is provided in Table 4.

Table 4. Other meteorological parameters used for the CAP88-PC modeling.

\begin{tabular}{lcc}
\hline Variable & Value $^{\mathrm{a}}$ & Units \\
\hline Lid height & 800 & meters \\
Mean temperature & 280.2 & Kelvin \\
Annual Precipitation & 20.8 & $\mathrm{~cm} / \mathrm{year}$ \\
Absolute humidity & 3.54 & $\mathrm{~g} / \mathrm{m}^{3}$ \\
\hline
\end{tabular}

a. Values represent a 10-year average at the INL (Clawson et al. 1989).

\section{Radionuclide Data}

Each of the radionuclides was modeled using the default chemical form, absorption type, and particle size. In this case, all were modeled as particulate of size 1 micron per FGR13 model data. The CAP88$\mathrm{PC}$ default absorption type for each radionuclide is $\mathrm{M}$ (medium) with the exception of the cesium radionuclides which are $F$ (fast).

\section{Air Pathway Dose Results}

Annual dose results for low-level chronic exposure to emissions from presumed normal operations of proposed HALEU processing facilities are shown in Tables 5 through 7 . Tables 5 and 6 contain the public dose estimates for Alternative $1 \mathrm{a}$ and $1 \mathrm{~b}$ respectively. Table 7 contains collocated worker doses for both alternatives.

Table 5. Public dose estimates for Alternative 1a (5,000 kg processed at MFC).

\begin{tabular}{lcc}
\hline Potential Receptor Location & $\begin{array}{c}\text { Receptor Distance and } \\
\text { Direction from Source }\end{array}$ & $\begin{array}{c}\text { Potential Dose } \\
\text { (mrem/yr) }\end{array}$ \\
\hline INL Site Boundary Nearest MFC & $5 \mathrm{~km} \mathrm{SSE}$ & $5.4^{\mathrm{b}}$ \\
Residence Nearest MFC & $9 \mathrm{~km} \mathrm{SSE}$ & $2.4^{\mathrm{e}}$ \\
Atomic City & $21 \mathrm{~km} \mathrm{SW}$ & 1.9 \\
INL MEl (Frenchman's Cabin) & $37 \mathrm{~km} \mathrm{WSW}$ & 0.74 \\
\hline a. Rounded to the nearest kilometer from INTEC entrance. & \\
b. Regulatory dose limits do not apply to this location. Dose results are presented only for reference. \\
c. Farmhouse located 3.1 km south of Highway 20, 3 km east of INL entrance. \\
d. Distance to nearest Atomic City residence. \\
e. Highest potential dose at an offsite location with a residence, school, business or office.
\end{tabular}


TEM-10200-1

$12 / 19 / 17$

ENGINEERING CALCULATIONS AND ANALYSIS

Page 12 of 18

Rev. 08

Evaluation of Impacts from Radiological Air Emissions for the HALEU Environmental

Title: $\quad$ Assessment

$\begin{array}{lllll}\text { ECAR No.: } 4321 & \text { Rev. No.: } & 0 & \text { Project No.: } & \text { N/A }\end{array}$

Table 6. Public dose estimates for Alternative $1 \mathrm{~b}(2,500 \mathrm{~kg}$ processed at both MFC and INTEC).

\begin{tabular}{lcccc}
\hline Potential Receptor Location & $\begin{array}{c}\text { Receptor } \\
\text { Distance and } \\
\text { Direction from } \\
\text { Source }\end{array}$ & $\begin{array}{c}\text { Potential Dose } \\
\text { Contribution } \\
\text { from INTEC } \\
\text { (mrem/yr) }\end{array}$ & $\begin{array}{c}\text { Potential Dose } \\
\text { Contribution } \\
\text { from MFC } \\
\text { (mrem/yr) }\end{array}$ & $\begin{array}{c}\text { Total } \\
\text { Potential } \\
\text { Dose } \\
\text { (mrem/yr) }\end{array}$ \\
\hline INL Site Boundary Nearest INTEC $^{\mathrm{b}}$ & $14 \mathrm{~km} \mathrm{~S}^{\mathrm{c}}$ & $1.6^{\mathrm{b}}$ & $0.59^{\mathrm{b}}$ & $2.2^{\mathrm{b}}$ \\
Atomic City (Residence Nearest INTEC) $^{\mathrm{d}}$ & $17 \mathrm{~km} \mathrm{SE}$ & 0.55 & 0.93 & 1.5 \\
INL MEI (Frenchman's Cabin) $^{\text {INL }}$ & $19 \mathrm{~km} \mathrm{SSW}$ & 1.2 & 0.37 & $1.6^{\mathrm{e}}$ \\
INL Site Boundary Nearest MFC $^{\mathrm{b}}$ & $24 \mathrm{~km} \mathrm{E}$ & $0.40^{\mathrm{b}}$ & $2.7^{\mathrm{b}}$ & $3.1^{\mathrm{b}}$ \\
Residence Nearest MFC & $27 \mathrm{~km} \mathrm{E}$ & 0.33 & 1.2 & 1.5 \\
\hline
\end{tabular}

a. $\quad$ Rounded to the nearest kilometer from Fuel Conditioning Facility at MFC (MFC-765).

b. Regulatory limits do not apply to this location. Dose results are presented for reference only.

c. The INL Site boundary northwest of INTEC is the same distance as the nearest southern boundary, yet the dose at nearest southern boundary is higher.

d. Atomic City is the location nearest INTEC with a residence. Distance is to nearest residence in Atomic City.

e. Highest potential dose at a location with a residence, school, business or office.

Table 7. Collocated worker dose estimates for Alternatives $1 \mathrm{a}$ and $1 \mathrm{~b}$.

\begin{tabular}{lcc}
\hline Alternative & $\begin{array}{r}\text { INTEC Worker Dose } \\
\text { (mrem/yr)a }\end{array}$ & $\begin{array}{c}\text { MFC Worker Dose } \\
\text { (mrem/yr) }\end{array}$ \\
\hline 1a (5,000 kg processed at MFC) & NA & 48 \\
1b (2,500 kg processed at both MFC and INTEC) & 33 & 24 \\
\hline
\end{tabular}

\section{Dose Results Compared to Regulatory Limits}

$40 \mathrm{CR}$ 61, Subpart $\mathrm{H}$ has established the public dose limit for radionuclide emissions to ambient air from all DOE facilities as $10 \mathrm{mrem} / \mathrm{yr}$ effective dose equivalent. This applies at any offsite location where there is a residence, school, business, or office. A residence is defined as any home, house, apartment building, or other place of dwelling which is occupied during any portion of the year. For workers, the DOE Occupational Radiation Protection (10 CFR 835) specifies the dose limit for general employees from DOE sources as 5,000 mrem/yr total effective dose.

The results in Tables 5 and 6 show the estimated potential public doses associated with HALEU fuel fabrication are less than the $10 \mathrm{mrem} / \mathrm{yr}$ regulatory standard. The largest potential dose from

Alternative $1 \mathrm{a}$ is $2.4 \mathrm{mrem} / \mathrm{yr}$ at residence nearest to MFC, the farmhouse located south of Highway 20 near the INL entrance. The largest potential dose from Alternative $1 \mathrm{~b}$ is $1.6 \mathrm{mrem} / \mathrm{yr}$ at Frenchman's cabin, the INL MEI location. Potential cumulative-dose impacts to the public associated with HALEU fuel fabrication and other INL activities are assessed in the Environmental Assessment (DOE-EA 2018). The estimated collocated-worker potential doses in Table 7 are significantly less than the 5,000 $\mathrm{mrem} / \mathrm{yr}$ regulatory dose standard for both alternatives. The largest dose is from Alternative 1a at 48 $\mathrm{mrem} / \mathrm{yr}$. It is not surprising the largest dose comes from Alternative 1a given that both processing facilities were assumed to be collocated at MFC.

\section{Surface Soil Exposure Assessment}

Estimated potential doses to public receptors (Tables 5 and 6) and collocated workers (Table 7) from atmospheric emissions include doses due to air immersion, inhalation of contaminated air, ingestion of 
TEM-10200-1

$12 / 19 / 17$

Rev. 08

Evaluation of Impacts from Radiological Air Emissions for the HALEU Environmental

Title: $\quad$ Assessment

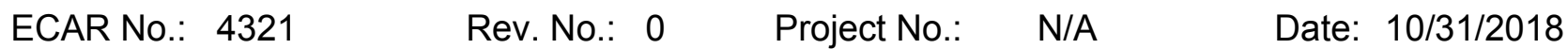

contaminated food products, and direct radiation from ground deposition. Additional impacts not considered in those calculations (incidental ingestion of contaminated soil and inhalation of fugitive dust) were assessed using a screening-level analysis. These additional pathways are less significant during the operational phase and become important typically after operations have ceased. Direct radiation and ingestion of food products are also important after operations, but doses after operations are bounded by the doses calculated during operations in Tables 5 and 6 .

Concentrations of radionuclides in soil due to buildup of particulate deposition were calculated and compared to pathway-specific EPA preliminary remediation goals (PRGs). PRGs are risk-based soil concentrations derived from standardized equations combining exposure-information assumptions with EPA toxicity data. They are soil concentrations that would not likely result in adverse health impacts under reasonable maximum exposure conditions for long-term/chronic exposures. For this assessment, PRGs are based on a target lifetime cancer risk of 1E-06, meaning that a person exposed to the contamination has a one-in-one-million chance of developing cancer. The EPA PRG database is based on EPAs Risk Assessment Guidance for Superfund: Volume I, Human Health Evaluation Manual (Part B, Development of Risk-based Preliminary Remediation Goals [RAGS] Part B) (EPA 1991). PRG values were downloaded from the EPA website https://epa-prgs.ornl.gov/radionuclides/download.html.

The maximum soil concentrations anywhere were used for the comparison, even though they would be significantly greater than concentrations at any public receptor location. This was done because the soil-ingestion and dust-inhalation exposure pathways are generally less significant than the exposure pathways included in CAP88-PC dose calculations (especially while the source is active), and the maximum soil concentrations could be used to bound the impacts.

Maximum soil concentrations were calculated from maximum ground-deposition rates provided in the CAP88-PC model output. For both MFC and INTEC, maximum deposition was found to occur $200 \mathrm{~m}$ from the stack in the NE direction. This was determined by plotting dose as a function of distance from the source for each of the 16 sectors. Total dose was used as a surrogate for ground-deposition rates because, for this investigation, the dose is dominated by the direct ground-surface radiation pathway. In addition, the $200 \mathrm{~m}$ distance would likely be the shortest distance from a production facility to a location outside the MFC or INTEC fence.

Soil concentrations were calculated using a first-order kinetic expression from Whicker and Rood (2008) that includes leaching, but was modified to also account for radioactive decay:

$C_{s}=\frac{R}{k_{r}+k_{l}}\left[1-e^{\left(k_{r}+k_{l}\right) t}\right]$

where $C_{s}=$ concentration in soil surface at time $\mathrm{t}\left(\mathrm{pCi} / \mathrm{cm}^{2}\right)$

$R=$ ground deposition rate $\left(\mathrm{pCi} / \mathrm{cm}^{2} / \mathrm{yr}\right)$

$k_{r}=$ radioactive decay rate constant $\left(\mathrm{yr}^{-1}\right)$

$k_{l}=$ leach rate constant $\left(\mathrm{yr}^{-1}\right)$

$t=$ operational period $(\mathrm{yr})$.

The radioactive decay rate constant is defined as

$k_{r}=\frac{\ln (2)}{t_{1 / 2}}$ 
TEM-10200-1

$12 / 19 / 17$

ENGINEERING CALCULATIONS AND ANALYSIS

Page 14 of 18

Rev. 08

Evaluation of Impacts from Radiological Air Emissions for the HALEU Environmental

Title: $\quad$ Assessment

$\begin{array}{lllll}\text { ECAR No.: } 4321 & \text { Rev. No.: } & 0 & \text { Project No.: N/A } & \text { Date: } 10 / 31 / 2018\end{array}$

Where $t_{1 / 2}=$ radionuclide half-life $(\mathrm{yr})$.

Leach rate constants were calculated with the following expression from Rood (2003).

$k_{l}=\frac{I}{T \theta R_{d}}$

where $I=$ Infiltration rate $(\mathrm{cm} / \mathrm{yr})$

$T=$ thickness of contaminated layer $(\mathrm{cm})$

$\theta=$ soil moisture content (dimensionless)

$R_{d}=$ retardation coefficient (dimensionless).

The retardation coefficient $R_{d}$ is given by the expression:

$R_{d}=1+\frac{\rho k_{d}}{\theta}$

where $\rho=$ soil bulk density $\left(\mathrm{g} / \mathrm{cm}^{3}\right)$

$k_{d}=$ soil distribution (sorption) coefficient $\left(\mathrm{cm}^{3} / \mathrm{g}\right)$

Inputs to the above expressions are provided in Tables 8 and 9. Maximum ground deposition rates and soil concentrations are provided in Table 10. Decay products are not included because the PRG values for most radionuclides (Cs-137, Sr-90, Np-237, Pu-239, U-235, and U-238) include the impact of decay products. This is typically the case for radionuclides with decay products that are in secular equilibrium with the parent radionuclide in the environment. For the remaining radionuclides (Pu-240, U-234, U236, U-232, U-233 and U-237), PRG values do not include the impact of decay products because the primary decay products are sufficiently long-lived that they are likely not in activity equilibrium with the parent radionuclide.

Table 8. Parameter values for surface soil concentration calculations.

\begin{tabular}{|c|c|c|}
\hline Parameter & Value & Source \\
\hline Operational period $(t)$ & 2 yrs & $\begin{array}{l}\text { Minimum time required to process } 10 \text { metric tons of HALEU } \\
\text { feedstock material at a rate of } 5,000 \mathrm{~kg} / \mathrm{yr}^{\mathrm{a}} \text {. }\end{array}$ \\
\hline Infiltration rate $(I)$ & $1 \mathrm{~cm} / \mathrm{yr}$ & $\begin{array}{l}\text { Typical infiltration rate at INL for undisturbed soils (Cecil et al. } \\
\text { 1992). Annual precipitation rate is approximately } 22 \mathrm{~cm} / \mathrm{yr} \text {. }\end{array}$ \\
\hline Soil thickness $(T)$ & $5 \mathrm{~cm}$ & Assumed value \\
\hline Soil moisture content $(\theta)$ & 0.3 & INL surface soil value from DOE-ID (1994) \\
\hline Soil bulk density $(\rho)$ & $1.5 \mathrm{~g} / \mathrm{cm}^{3}$ & INL surface soil value from DOE-ID (1994) \\
\hline
\end{tabular}

a. 10 metric tons is the estimated stockpile of HALEU material at INL expected to be processed into fuel. The highest processing rate and shortest operation period will produce the highest soil concentration rates. 
TEM-10200-1

$12 / 19 / 17$

Rev. 08

Evaluation of Impacts from Radiological Air Emissions for the HALEU Environmental

Title: $\quad$ Assessment

$\begin{array}{lllll}\text { ECAR No.: } 4321 & \text { Rev. No.: } 0 & \text { Project No.: N/A } & \text { Date: } 10 / 31 / 2018\end{array}$

Table 9. Radionuclide-specific parameters for surface soil concentration calculations.

\begin{tabular}{|c|c|c|c|c|c|}
\hline Radionuclide & $\begin{array}{c}\text { Half-life } \\
(y r)\end{array}$ & $\begin{array}{c}\text { Decay Rate } \\
\text { Constant } k_{r} \\
\left(y^{-1}\right)\end{array}$ & $\begin{array}{c}\text { Sorption } \\
\text { Coefficient } k_{d} \\
\left(\mathrm{~cm}^{3} / \mathrm{g}\right)^{\mathrm{a}}\end{array}$ & $\begin{array}{c}\text { Retardation } \\
\text { Coefficient } \\
R_{d} \\
\end{array}$ & $\begin{array}{c}\text { Leach Rate } \\
\text { Constant } k_{l} \\
\left(y^{-1}\right)\end{array}$ \\
\hline $\mathrm{Mn}-54$ & $8.55 E-01$ & 8.11E-01 & 50 & 251 & $2.66 \mathrm{E}-03$ \\
\hline Co-60 & $5.27 \mathrm{E}+00$ & 1.31E-01 & 10 & 51 & 1.31E-02 \\
\hline Sr-90 & $2.89 \mathrm{E}+01$ & 2.40E-02 & 24 & 121 & 5.51E-03 \\
\hline Tc-99 & $2.11 \mathrm{E}+05$ & $3.28 \mathrm{E}-06$ & 0.2 & 2 & 3.33E-01 \\
\hline Sb-125 & $2.76 \mathrm{E}+00$ & 2.51E-01 & 50 & 251 & 2.66E-03 \\
\hline Cs-134 & $2.07 \mathrm{E}+00$ & 3.36E-01 & 500 & 2501 & 2.67E-04 \\
\hline Cs-135 & $2.30 \mathrm{E}+06$ & 3.01E-07 & 500 & 2501 & 2.67E-04 \\
\hline Cs-137 & $3.01 \mathrm{E}+01$ & 2.30E-02 & 500 & 2501 & 2.67E-04 \\
\hline Ce-144 & 7.80E-01 & 8.89E-01 & 500 & 2501 & 2.67E-04 \\
\hline Eu-154 & $8.60 \mathrm{E}+00$ & 8.06E-02 & 340 & 1701 & 3.92E-04 \\
\hline Eu-155 & $4.75 \mathrm{E}+00$ & 1.46E-01 & 340 & 1701 & 3.92E-04 \\
\hline Np-237 & $2.14 \mathrm{E}+05$ & 3.24E-06 & 18 & 91 & 7.33E-03 \\
\hline Pu-239 & $2.41 \mathrm{E}+04$ & 2.87E-05 & 1480 & 7401 & 9.01E-05 \\
\hline Pu-240 & $6.56 \mathrm{E}+03$ & 1.06E-04 & 1480 & 7401 & 9.01E-05 \\
\hline Am-241 & $4.33 \mathrm{E}+02$ & 1.60E-03 & 340 & 1701 & 3.92E-04 \\
\hline U-234 & $2.46 \mathrm{E}+05$ & 2.82E-06 & 10 & 51 & 1.31E-02 \\
\hline U-235 & $7.04 \mathrm{E}+08$ & $9.85 \mathrm{E}-10$ & 10 & 51 & 1.31E-02 \\
\hline U-236 & $2.34 \mathrm{E}+07$ & 2.96E-08 & 10 & 51 & 1.31E-02 \\
\hline U-238 & 4.47E+09 & $1.55 \mathrm{E}-10$ & 10 & 51 & 1.31E-02 \\
\hline U-232 & $6.89 \mathrm{E}+01$ & 1.01E-02 & 10 & 51 & 1.31E-02 \\
\hline U-233 & $1.59 \mathrm{E}+05$ & 4.35E-06 & 10 & 51 & 1.31E-02 \\
\hline U-237 & 1.85E-02 & $3.75 E+01$ & 10 & 51 & 1.31E-02 \\
\hline
\end{tabular}

a. Maximum value for alluvium from Jenkins (2001), DOE-ID (1994), and DOE-ID (2018). 
Rev. 08

Evaluation of Impacts from Radiological Air Emissions for the HALEU Environmental

Title: $\quad$ Assessment

$\begin{array}{lllll}\text { ECAR No.: } 4321 & \text { Rev. No.: } 0 & \text { Project No.: N/A } & \text { Date: } 10 / 31 / 2018\end{array}$

Table 10. Comparison of radionuclide soil concentrations to EPA PRGs.

\begin{tabular}{|c|c|c|c|c|c|c|c|}
\hline Nuclide & $\begin{array}{c}\text { Max Soil } \\
\text { Deposition } \\
\text { Rate outside } \\
\text { MFC } \\
\left(\mathrm{pCi} / \mathrm{cm}^{2} / \mathrm{yr}\right)^{\mathrm{a}} \\
\end{array}$ & $\begin{array}{c}\text { Max Soil } \\
\text { Deposition } \\
\text { Rate INTEC } \\
\left(\mathrm{pCi} / \mathrm{cm}^{2} / \mathrm{yr}\right)^{\mathrm{b}}\end{array}$ & $\begin{array}{c}\text { Max Soil } \\
\text { Concentration } \\
\text { outside MFC } \\
(\mathrm{pCi} / \mathrm{g})^{\mathrm{a}}\end{array}$ & $\begin{array}{c}\text { Max Soil } \\
\text { Concentration } \\
\text { outside INTEC } \\
(p \mathrm{Ci} / \mathrm{g})^{\mathrm{b}} \\
\end{array}$ & $\begin{array}{c}\text { EPA PRG } \\
\text { for Soil } \\
\text { Ingestion } \\
\text { and } \\
\text { Inhalation }^{\mathrm{c}} \\
\end{array}$ & $\begin{array}{c}\text { Ratio of MFC } \\
\text { Max Soil } \\
\text { Concentration } \\
\text { to EPA PRG }\end{array}$ & $\begin{array}{c}\text { Ratio of INTEC } \\
\text { Max Soil } \\
\text { Concentration } \\
\text { to EPA PRG }\end{array}$ \\
\hline$M n-54$ & 1.64E-01 & 1.13E-01 & 2.16E-02 & 1.49E-02 & $3.8 \mathrm{E}+03$ & 5.69E-06 & 3.92E-06 \\
\hline Co-60 & $2.18 \mathrm{E}-04$ & $1.51 \mathrm{E}-04$ & 5.06E-05 & 3.49E-05 & $8.3 E+01$ & $6.09 \mathrm{E}-07$ & $4.20 \mathrm{E}-07$ \\
\hline Sr-90 & $1.50 \mathrm{E}+01$ & $1.04 \mathrm{E}+01$ & $3.89 \mathrm{E}+00$ & $2.68 \mathrm{E}+00$ & $8.9 \mathrm{E}+00$ & 4.37E-01 & 3.01E-01 \\
\hline Tc-99 & $1.78 \mathrm{E}-08$ & $1.23 \mathrm{E}-08$ & 3.46E-09 & 2.39E-09 & $1.2 \mathrm{E}+02$ & $2.89 \mathrm{E}-11$ & $1.99 \mathrm{E}-11$ \\
\hline Sb-125 & 7.45E-01 & $5.11 \mathrm{E}-01$ & 1.56E-01 & $1.07 \mathrm{E}-01$ & $5.4 \mathrm{E}+02$ & $2.88 \mathrm{E}-04$ & $1.98 \mathrm{E}-04$ \\
\hline Cs-134 & $2.24 \mathrm{E}-01$ & $1.54 \mathrm{E}-01$ & 4.35E-02 & 3.00E-02 & $1.4 \mathrm{E}+02$ & $3.11 \mathrm{E}-04$ & 2.14E-04 \\
\hline Cs-135 & 2.13E-02 & 1.47E-02 & $5.69 \mathrm{E}-03$ & $3.92 \mathrm{E}-03$ & $9.6 \mathrm{E}+01$ & 5.93E-05 & 4.09E-05 \\
\hline Cs-137 & $4.84 \mathrm{E}+00$ & $3.35 \mathrm{E}+00$ & $1.26 \mathrm{E}+00$ & $8.72 E-01$ & $2.8 \mathrm{E}+01$ & 4.51E-02 & 3.11E-02 \\
\hline Ce-144 & $1.48 \mathrm{E}-03$ & $1.02 \mathrm{E}-03$ & $1.85 \mathrm{E}-04$ & 1.27E-04 & $2.2 E+02$ & $8.41 \mathrm{E}-07$ & 5.79E-07 \\
\hline Eu-154 & 4.14E-01 & $2.86 \mathrm{E}-01$ & $1.02 \mathrm{E}-01$ & 7.03E-02 & $8.4 \mathrm{E}+01$ & $1.21 \mathrm{E}-03$ & 8.38E-04 \\
\hline Eu-155 & $7.45 \mathrm{E}-01$ & $5.11 \mathrm{E}-01$ & $1.72 \mathrm{E}-01$ & $1.18 \mathrm{E}-01$ & $6.7 \mathrm{E}+02$ & $2.57 \mathrm{E}-04$ & 1.76E-04 \\
\hline $\mathrm{Np}-237$ & 8.39E-05 & $5.78 \mathrm{E}-05$ & $2.22 \mathrm{E}-05$ & $1.53 \mathrm{E}-05$ & $6.2 \mathrm{E}+00$ & 3.60E-06 & $2.48 \mathrm{E}-06$ \\
\hline Pu-239 & 3.62E-02 & 2.49E-02 & $9.64 \mathrm{E}-03$ & $6.64 \mathrm{E}-03$ & $3.8 \mathrm{E}+00$ & $2.54 \mathrm{E}-03$ & $1.75 \mathrm{E}-03$ \\
\hline Pu-240 & $3.53 \mathrm{E}-03$ & 2.43E-03 & $9.42 \mathrm{E}-04$ & $6.49 \mathrm{E}-04$ & $3.8 \mathrm{E}+00$ & $2.48 \mathrm{E}-04$ & $1.71 \mathrm{E}-04$ \\
\hline Am-241 & $1.46 \mathrm{E}+00$ & $1.01 \mathrm{E}+00$ & 3.88E-01 & $2.68 \mathrm{E}-01$ & $4.8 \mathrm{E}+00$ & 8.09E-02 & $5.58 \mathrm{E}-02$ \\
\hline U-234 & $6.88 \mathrm{E}-02$ & 4.77E-02 & $1.81 \mathrm{E}-02$ & $1.25 \mathrm{E}-02$ & $5.9 \mathrm{E}+00$ & $3.08 \mathrm{E}-03$ & $2.13 \mathrm{E}-03$ \\
\hline U-235 & $2.89 \mathrm{E}-03$ & $1.99 \mathrm{E}-03$ & 7.61E-04 & $5.24 \mathrm{E}-04$ & $5.7 \mathrm{E}+00$ & 1.33E-04 & $9.19 E-05$ \\
\hline U-236 & 2.33E-03 & $1.61 \mathrm{E}-03$ & $6.13 E-04$ & 4.23E-04 & $6.3 \mathrm{E}+00$ & 9.77E-05 & $6.74 \mathrm{E}-05$ \\
\hline U-238 & $1.86 \mathrm{E}-03$ & $1.28 \mathrm{E}-03$ & 4.88E-04 & 3.37E-04 & $4.4 \mathrm{E}+00$ & 1.10E-04 & 7.59E-05 \\
\hline U-232 & 7.70E-04 & 5.30E-04 & 2.01E-04 & $1.38 \mathrm{E}-04$ & $1.9 \mathrm{E}+00$ & $1.08 \mathrm{E}-04$ & 7.41E-05 \\
\hline U-233 & 2.13E-05 & 1.47E-05 & $5.62 \mathrm{E}-06$ & 3.87E-06 & $5.8 \mathrm{E}+00$ & $9.70 \mathrm{E}-07$ & 6.69E-07 \\
\hline U-237 & $1.25 \mathrm{E}+00$ & $8.62 \mathrm{E}-01$ & 4.44E-07 & $3.06 \mathrm{E}-07$ & $6.5 \mathrm{E}+04$ & $6.83 \mathrm{E}-12$ & $4.71 \mathrm{E}-12$ \\
\hline \multicolumn{6}{|c|}{ Sum-of-Ratios ${ }^{d}$} & 0.57 & 0.39 \\
\hline
\end{tabular}

a. MFC soil deposition and concentration based on annual emission of $5,000 \mathrm{~kg}(2,500 \mathrm{~kg}$ per facility). Facilities are assumed collocated.

b. INTEC soil deposition and concentration based on annual emission rate of $2,500 \mathrm{~kg}$.

c. PRGs are based on a target cancer risk of 1E-06. PRG is the total PRG for the soil ingestion and inhalation of fugitive dust pathways. The total PRG is dominated by the ingestion PRG.

d. Sum-of-ratios less than 1 indicates concentrations will likely not result in adverse human health impacts.

The results in Table 10 indicate that all maximum radionuclide soil concentrations are less than EPA PRGs, and the sum-of-ratios less than one indicates the risk of developing cancer from the contaminated soils is less than one in one million.

\section{SUMMARY AND CONCLUSIONS}

Potential radionuclide emissions from operations at proposed HALEU fuel production facilities and subsequent doses from low-level chronic exposure were estimated using methodologies and assumptions consistent with regulatory standards and approved guidance. Impacts from exposure to contaminated soils after processing is complete were evaluated by calculating by maximum soil concentrations due to deposition and buildup and comparing the results to EPA risk-based screening levels.

Table 11 provides a summary of all impacts and comparisons to selected performance standards, which include enforceable regulatory limits and screening levels. The results indicate that impacts from proposed production of HALEU fuel using Alternative $1 \mathrm{a}$ or Alternative $1 \mathrm{~b}$ are less than applicable 
TEM-10200-1

$12 / 19 / 17$

ENGINEERING CALCULATIONS AND ANALYSIS

Page 17 of 18

Rev. 08

Evaluation of Impacts from Radiological Air Emissions for the HALEU Environmental

Title: $\quad$ Assessment

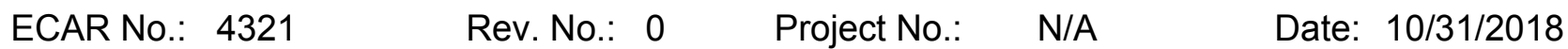

standards. Alternative 1a impacts are slightly greater than Alternative $1 \mathrm{~b}$ because all processing for Alternative $1 \mathrm{a}$ is performed at MFC, and the 2 facilities were conservatively assumed to be collocated for purposes of determining impacts.

Impacts are based on maximum, unabated/unmitigated potential emissions and conservative or bounding assumptions. Therefore, the impacts are assumed to represent screening or bounding-level estimates.

Table 11. Impacts summary for HALEU fuel production.

\begin{tabular}{|c|c|c|c|}
\hline Performance Measure & $\begin{array}{l}\text { Alternative 1a } \\
\text { Potential Impact }\end{array}$ & $\begin{array}{l}\text { Alternative 1b } \\
\text { Potential Impact }\end{array}$ & Performance Standard \\
\hline $\begin{array}{l}\text { Maximum potential dose at } \\
\text { nearest INL Site boundary }\end{array}$ & $\begin{array}{l}5.4 \mathrm{mrem} / \mathrm{yr}(5 \mathrm{~km} \mathrm{SSE} \\
\text { of MFC) }\end{array}$ & $\begin{array}{l}3.1 \mathrm{mrem} / \mathrm{yr}(5 \mathrm{~km} \text { SSE of } \\
\text { MFC) }\end{array}$ & $\begin{array}{l}\text { Regulatory standards do not apply. } \\
\text { Results presented for reference only. }\end{array}$ \\
\hline $\begin{array}{l}\text { Maximum potential dose at a } \\
\text { public residence }\end{array}$ & $\begin{array}{l}2.4 \mathrm{mrem} / \mathrm{yr} \text { (Farmhouse } \\
9 \mathrm{~km} \text { SSE of MFC) }\end{array}$ & $\begin{array}{l}1.6 \mathrm{mrem} / \mathrm{yr} \text { (Frenchman's } \\
\text { cabin) }^{\mathrm{a}}\end{array}$ & $\begin{array}{l}10 \mathrm{mrem} / \mathrm{yr} \text { from all emission sources } \\
(40 \mathrm{CFR} 61 \text {, Subpart } \mathrm{H})^{\mathrm{b}}\end{array}$ \\
\hline $\begin{array}{l}\text { Maximum potential dose at INL } \\
\text { MEI (Frenchman's cabin) }\end{array}$ & $0.74 \mathrm{mrem} / \mathrm{yr}$ & $1.6 \mathrm{mrem} / \mathrm{yr}$ & $\begin{array}{l}10 \mathrm{mrem} / \mathrm{yr} \text { from all emission sources } \\
(40 \text { CFR } 61 \text {, Subpart } \mathrm{H})^{\mathrm{b}}\end{array}$ \\
\hline $\begin{array}{l}\text { Maximum potential dose to } \\
\text { collocated worker }\end{array}$ & $\begin{array}{l}48 \mathrm{mrem} / \mathrm{yr}(100 \mathrm{~m} \text { from } \\
\text { MFC facilities) }\end{array}$ & $\begin{array}{l}33 \mathrm{mrem} / \mathrm{yr}(100 \mathrm{~m} \text { from } \\
\text { INTEC facility) }\end{array}$ & $\begin{array}{l}5,000 \mathrm{mrem} / \mathrm{yr} \text { total effective dose } \\
\text { (10 CFR 835) }\end{array}$ \\
\hline $\begin{array}{l}\text { Maximum soil concentrations } \\
\text { compared to EPA PRGs }\end{array}$ & Sum-of-Ratios $=0.57$ & Sum-of-Ratios = 0.39 & $\begin{array}{l}\text { Sum-of-Ratios }<1.0 \text { for cancer risk } \\
\text { less than } 1 \text { in } 1 \text { million }\end{array}$ \\
\hline
\end{tabular}

\section{REFERENCES}

10 CFR 835, 2015, U.S. Department of Energy Occupational Radiation Protection, Code of Federal Regulations.

40 CFR 61, Appendix D, "Methods for Estimating Radionuclide Emissions," Code of Federal Regulations, Office of the Federal Register, December 1989.

40 CFR 61, Subpart H, 2010, "National Emission Standards for Emissions of Radionuclides Other than Radon from Department of Energy Facilities," Code of Federal Regulations, Office of the Federal Register, April 2010.

CCN 241475, 2017, Letter from Donald Dossett (U.S. EPA Region 10) to Tim Safford (U.S. Department of Energy Idaho Operations Office), Oct 19, 2017.

CRC Handbook of Chemistry and Physics, 99th Edition (Internet Version 2018), John R. Rumble, editor, CRC Press/Taylor \& Francis, Boca Raton, FL.

Cecil, L.D., J.R. Pittman, T.M. Beasley, R.L. Michel, P.W. Kubik, P. Sharma, U. Fehn, and H. Gove, 1992, "Water Infiltration Rates in the Unsaturated Zone at the Idaho National Engineering Laboratory Estimated from Chlorine-36 and Tritium Profiles, and Neutron Logging," Proceedings 
Rev. 08

Evaluation of Impacts from Radiological Air Emissions for the HALEU Environmental

Title: $\quad$ Assessment

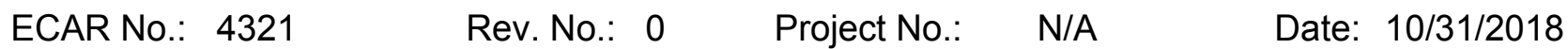

of the 7th International Symposium on Water-Rock Interaction, Park City, Utah, WRI-7, Rotterdam: Balkema.

Clawson, K. L., G. E. Start, and N. R. Ricks, 1989, Climatography of the Idaho National Engineering Laboratory, DOE/ID-12118, National Oceanic and Atmospheric Administration, Field Research Division, Idaho Falls, ID 83402.

DOE-ID 1994, Track 2 Sites: Guidance for Assessing Low Probability Hazard Sites at the INEL, DOEID-10389, U.S. Department of Energy Idaho Operations Office, August 1994.

DOE-ID 2018, Performance Assessment for the Idaho National Laboratory Remote-Handled Low-Level Waste Disposal Facility, DOE/ID-11421, Revision 2, U.S. Department of Energy Idaho Operations Office, February 2018.

DOE-EA 2018, Environmental Assessment for Use of DOE-Owned HALEU Stored at INL, DOE/EA2087 (Preliminary DRAFT), U.S. Department of Energy Idaho Operations Office, October 2018.

EPA, 1991, Risk Assessment Guidance for Superfund, Volume I: Human Health Evaluation Manual (Part B, Development of Risk-Based Preliminary Remediation Goals), U.S. Environmental Protection Agency, Office of Emergency and Remedial Response, EPA/540/R-92/003, December 1991, (https://www.epa.gov/risk/risk-assessment-guidance-superfund-rags-part-b).

EPA 2013a, “CAP88-PC Version 4.0 User's Guide," Trinity Engineering Associates, Inc., Cincinnati, $\mathrm{OH}$, submitted to U.S. EPA, Office of Radiation and Indoor Air, May 2013.

EPA 2013b, “CAP88-PC Version 4 Testing Report,” Revision 1, Trinity Engineering Associates, Inc., Cincinnati, OH, submitted to U.S. EPA Office of Radiation and Indoor Air, June 2013.

Jenkins, T., 2001, U.S. Department of Energy Idaho Operations Office, letter, to Marty Doornbos, Idaho National Engineering and Environmental Laboratory, July 3, 2001, "Kd Values for INTEC Groundwater Modeling," EM-ER-01-115.

NNDC, 2018, National Nuclear Data Center, information extracted from the NuDat 2 database, http://www.nndc.bnl.gov/nudat2/, Brookhaven National Laboratory, Website accessed 10/21/18.

Rood, A. S., 2003, GWSCREEN: A Semi-Analytical Model for Assessment of the Groundwater Pathway from Surface or Buried Contamination, Theory and User's Manual, Version 2.5, INEEL/EXT-98-00750, Idaho National Engineering and Environmental Laboratory, April 2003.

Staley, C. S., M. L. Abbott, and P. D. Ritter, 2004, INEEL Air Modeling Protocol, INEEL/EXT-04-02511, Idaho National Laboratory, December 2004.

TEV-3537 2018, Isotopic Characterization of HALEU from EBR-II Driver Fuel Processing, TEV-3537, October 2018.

Whicker, F.W, and A.S. Rood, 2008, Terrestrial Food Chain Pathways: Concepts and Models, in Radiological Risk Assessment and Environmental Analysis, Till, J.E., and H.A. Grogan (Eds.), Oxford University Press, 2008. 
TEM-10200-1

$12 / 19 / 17$

ENGINEERING CALCULATIONS AND ANALYSIS

Page $\mathrm{A} 1$ of $\mathrm{A} 2$

Rev. 08

Title:

ECAR No.: $X X X X$

Rev. No.: 0

Project No.:

N/A

Date: $10 / 31 / 2018$

Appendix A

CAP88-PC Windfiles

Windfile: EBRL6-15.WND

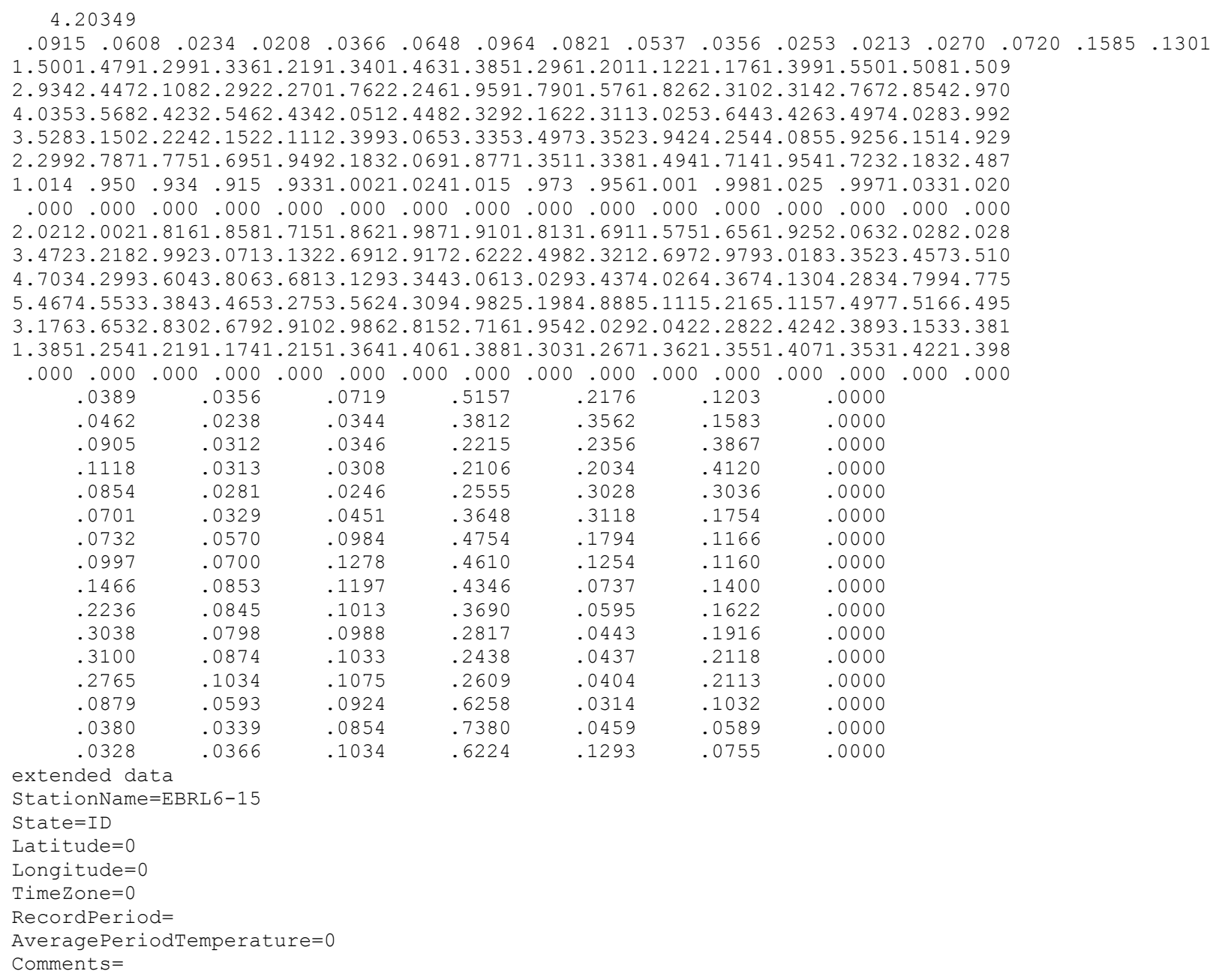

Windfile: GRIL6-15.WND

\footnotetext{
4.04579

$\begin{array}{lllllllllllllllll}.0497 & .0279 & 0164 & .0133 & .0181 & .0405 & .1119 & .1065 & .0718 & .0322 & .0208 & .0223 & .0400 & .1249 & .2108 & .0932\end{array}$ 1.5711 .4551 .4151 .3111 .3581 .4161 .4241 .2281 .0731 .0551 .0761 .1091 .3371 .4191 .5631 .587 2.5452 .4742 .3032 .0312 .1992 .1812 .3641 .8881 .6791 .7151 .6922 .2592 .1202 .5872 .7732 .804 3.2303 .7313 .1182 .4991 .9202 .6522 .9032 .4462 .1592 .0462 .1262 .4363 .1203 .3833 .9403 .701 3.3933 .3892 .9992 .5952 .3873 .1543 .3332 .8432 .5692 .3232 .1682 .6763 .1424 .8045 .1633 .855 2.0432 .1132 .0831 .6021 .5932 .2612 .3882 .2101 .6011 .1541 .2521 .4261 .6402 .2592 .5582 .301 1.1691 .1471 .0381 .0841 .0391 .0711 .0961 .0831 .089 .989 .9911 .0251 .0911 .1371 .1921 .218 $\begin{array}{llllllllllllllllllll}.000 & .000 & .000 & .000 & .000 & .000 & .000 & .000 & .000 & .000 & .000 & .000 & .000 & .000 & .000 & .000\end{array}$ 2.0801 .9801 .9411 .8301 .8821 .9421 .9501 .7271 .4941 .4621 .4991 .5531 .8601 .9452 .0742 .093 3.1823 .2833 .0282 .8262 .8632 .8912 .9462 .6302 .5142 .7622 .7163 .1062 .9843 .3313 .4603 .393 4.1904 .3884 .1983 .9083 .2773 .5433 .6203 .2903 .5163 .6793 .6343 .9294 .2704 .4254 .7664 .529 4.5724 .2703 .9323 .5283 .3814 .5654 .5454 .0014 .1134 .2713 .7784 .7674 .9696 .9446 .9175 .236 2.8163 .0022 .7312 .2962 .3663 .0833 .1492 .9102 .2691 .6511 .8402 .0702 .4463 .1283 .3573 .109 1.6471 .6131 .4311 .5131 .4341 .4911 .5331 .5101 .5211 .3361 .3401 .4071 .5251 .5981 .6781 .715
} 
TEM-10200-1

$12 / 19 / 17$

Rev. 08

ENGINEERING CALCULATIONS AND ANALYSIS

Page A2 of A2

Title:

ECAR No.: $\quad X X X X$

Rev. No.: $0 \quad$ Project No.: N/A

Date: $10 / 31 / 2018$

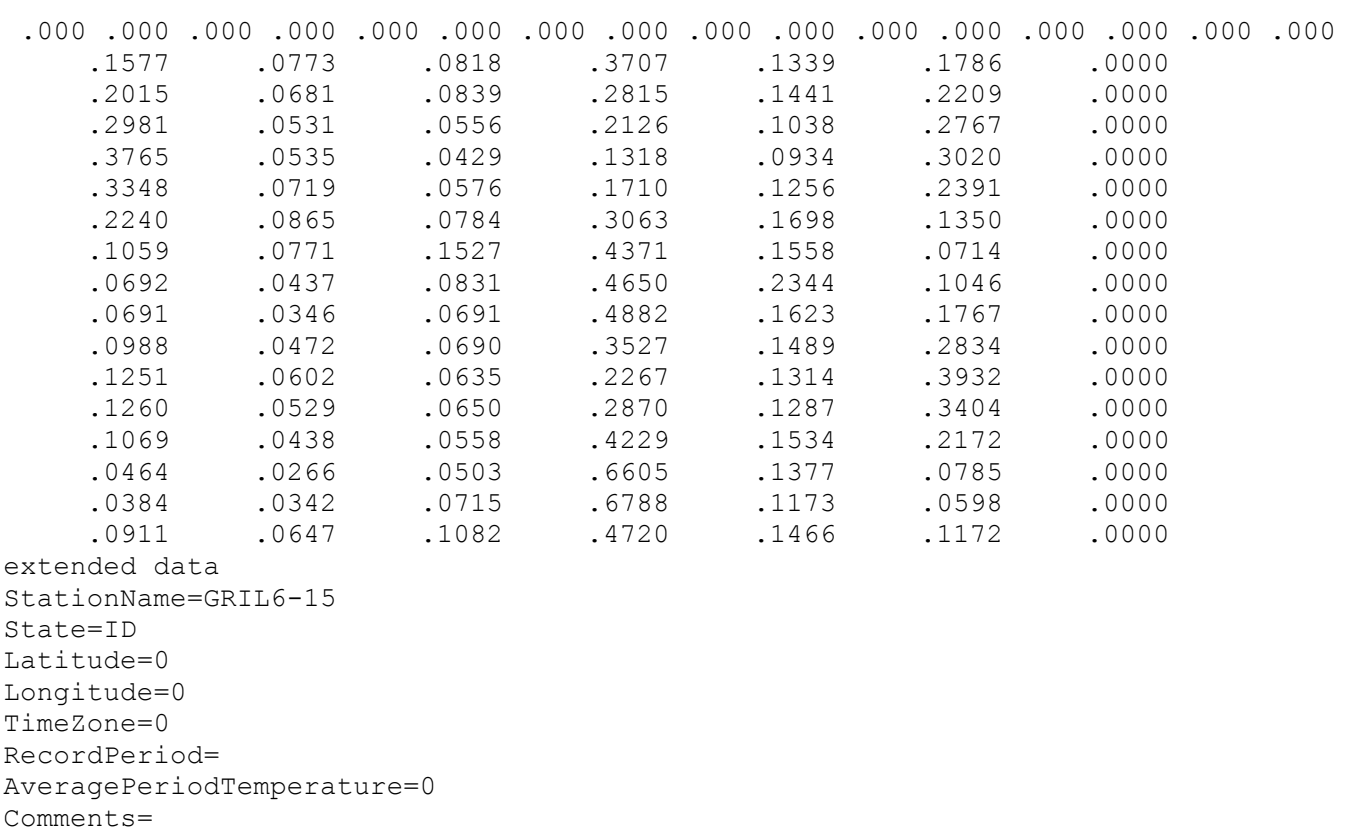

